\title{
Effect of Azadirachta excelsa and Melia azedarach extracts on soybean germination
}

\author{
RUMMI AZAHRA GUMILAR ${ }^{1, \vartheta}$, NURHENI WIJAYANTO ${ }^{2, v »}$, ARUM SEKAR WULANDARI $^{2}$ \\ 1 Graduate Program in Tropical Silviculture, Department of Silviculture, Faculty of Forestry, Institut Pertanian Bogor. Jl. Lingkar Akademik Kampus IPB \\ Darmaga, Bogor 16680, West Java, Indonesia. "email: azahrarummi@gmail.com \\ 2Department of Silviculture, Faculty of Forestry, Institut Pertanian Bogor. Jl. Lingkar Akademik Kampus IPB Darmaga, Bogor 16680, PO BOX 168- \\ 16001, West Java, Indonesia. Tel. +62-251-8626806, “”email: nurheniw@gmail.com.
}

Manuscript received: 13 April 2017. Revision accepted: 18 October 2017.

\begin{abstract}
Gumilar RA, Wijayanto N, Wulandari AS. 2017. Effect of Azadirachta excelsa and Melia azedarach extracts on soybean germination. Nusantara Bioscience 9: 346-351. Azadirachta excelsa and Melia azedarach are potential tree species developed in agroforestry system. Both plants are fast growing species and good for timber use. However, there is an inadequacy on both species due to their allelopathic compound contents. Allelopathic compounds in the plants are distributed from root, stem, leaf, and fruit; which at certain concentrations could inhibit germination, growth, and development of other plants. The objective of this study was to analyze the effects of root, leaf, and twig extracts of $M$. azedarach and A. excelsa on the germination of soybean. Result of this study showed that the root, leaf, and twig extracts of $M$. azedarach and A. excelsa were able to inhibit the development of soybean. $5 \%$ twig extract of $M$. azedarach significantly inhibited the germination by $77.75 \%$. Leaf and twig extracts of $A$. excelsa at $1.25 \%$ concentration has shown to provide stimulant effect on the germination of soybean.
\end{abstract}

Keywords: Agroforestry, allelopathy, germination, inhibition

\section{INTRODUCTION}

Azadirachta excelsa and Melia azedarach are species of trees which have potential to be developed in agroforestry system. In Malaysia and Thailand, Azadirachta excelsa has been developed extensively for forest plantations and agroforestry. Due to conical canopy with a balanced architecture, A. excelsa has the potential to be developed in agroforestry systems (Wibowo 2012). On the other hand, $M$. azedarach easily grows on a variety of soil conditions without intensive maintenance. These plants are found on community forest in West Java as part of mixed cropping systems.

A. excelsa and M. azedarach can be combined with many agricultural commodities in agroforestry system. Agroforestry system enables a more optimal land utilization, increase soil fertility and increase the high production of timber and agricultural crops when conducted with appropriate management. However, there is an inadequacy on A. excelsa and M. azedarach due to their allelopathic compound contents within the body tissue. Allelopathy is defined as biochemical interactions either beneficial or detrimental to the crop and weeds, or plants with microorganisms through the production of chemical compounds released into the environment and further affect the growth and development of surrounding plants (Sangheeta \& Baskar 2015). Allelopathy of a plant can affect growth and development of other crops through allelochemical compounds, toxic secondary metabolite which can be found in all plant tissues such as root, leaf and twig. Plant allelochemicals can lead to increased cell membrane permeability, inhibit plant root elongation, cell division, change ultra-structure, and then interfere with the normal growth and development of the whole plant.

Study on the allelopathic compound of A. excelsa has not been done so far. However, several studies have shown that the allelopathic compound from $M$. azedarach is capable of inhibiting the germination and growth of other plants. The objective of this study was to analyze the effect of $A$. excelsa and $M$. azedarach extracts on soybean germination. According to Lungu et al. (2011) M. azedarach contains allelopathic compound that may inhibit germination and growth of lettuce. It also inhibits the germination and growth of soybean and green beans. Soil from the root zone of $M$. azedarach is known to contain more allelopathic compound compared to soil treated with M. azedarach extract (Shapla et al. 2011). Stunted germination of plants will lead to the disruption of the growth in the later stages; besides the quality of seedlings and yield will also decrease. Therefore, the study on the effect of the allelopathic compound of A. axcelsa and M. azedarach on soybean is needed.

\section{MATERIALS AND METHODS}

\section{Study area}

This experiment was done in Seed Technology Laboratory of the Faculty of Agriculture, Bogor Agricultural University. Extract materials such as leaf, root, and twig of A. excelsa and M. azedarach were obtained from two-year-old stands in community-owned forests in 
Cikabayan, Darmaga. The chemical contents of extract materials were analyzed by the method of pyrolysis-gas chromatography-mass spectrometry (Py-GC-MS) at the Laboratory of Centre for Research and Development of Forestry Engineering and Forest Products Processing Bogor.

\section{Preparation of extract material}

Extract materials with a concentration of $10 \% \quad(\mathrm{w} / \mathrm{v})$ were obtained by mixing $10 \mathrm{~g}$ of the dried plant material with $100 \mathrm{~mL}$ of $70 \%$ ethanol. The extract was shaken for 24 hours at $150 \mathrm{rpm}$, at room temperature $\left( \pm 25^{\circ} \mathrm{c}\right)$. The extract was then paper filtered and allowed to stand until the alcohol evaporates. The remaining residual extract was used as a stock solution by adding $100 \mathrm{~mL}$ of distilled water and filtered through a filter paper. Extracts with concentration of $1.25 \%, 2.5 \%$, and $5 \%$ were obtained by diluting the stock solutions (Lungu et al., 2011).

\section{Soybean germination test in the laboratory}

Soybean used in this study was Argomulyo variety. Seeds used were obtained from the Center for Research and Development of Biotechnology and Genetics, Cimanggu, Bogor. Soybean germination test was conducted by rolled paper method which was then coated in plastic. Each roll was sprayed with $30 \mathrm{~mL}$ of the extract solution and 25 grains of soybean seeds were planted in a zigzag. Germination was observed every two days, started from 2 days after planting (DAP) to 7 DAP. The parameters observed in these experiments were: the percentage of germination, percentage of abnormal sprouts, as well as plumule and radicle length.

Germination percentage is the percentage of normal seedling produced at the optimum condition within a specified time. The criteria of normal sprouts were the long and straignt development of the root system especially the primary root, perfect hypocotyl growth, perfect plumule growth with green leaf and grow well, and intact cotyledon (Widajati et al. 2012). The characteristics of abnormal sprouts were the short primary root, no intact cotyledons, malformed shape , twisted plumule, swollen hypocotyl, and stunted sprouts. Allelopathic activities on soybean sprouts was analyzed by the following formulas:

Response index of germination (RI) (Hu et al. 2013):

$$
R I=\left(\frac{\text { The germination rate of treated seeds }}{\text { The germination rate of the control }}\right)-1
$$

The inhibition percentage of radicle growth (Tsao et al. 2002):

$$
\text { Inhibition }=\left(\frac{L_{\text {control }}-L_{\text {treatment }}}{L_{\text {control }}}\right) \times 100
$$

$L_{\text {control }}$ is redicle length of the control sprouts, and

$L_{\text {treatment }}$ is redicle length of the treated sprouts

\section{Experimental design}

This study used a completely randomized design factorial with three factors. The first factor was the plant species as the extract materials consisted of Azadirachta excelsa and Melia azedarach. The second factor was the part of the plant consisting of root, leaf, and twig. The third factor was the concentration of the extract consisting of four levels, $0 \%$ (control), 1.25\%, 2.5\%, and 5\%. Each treatment was repeated for 3 times.

\section{Data analysis}

Data were processed using SAS 9.1 software. To determine the effect of treatment, when significant effect of the variables was found, the analysis of variance (ANOVA) was conducted, followed by Duncan multiple range test.

\section{RESULTS AND DISCUSSION}

\section{Chemical compounds analysis}

Table 1 shows the allelochemical compounds which might provide an allelopathic effect and inhibit the germination of soybean. The results of pyrolysis GCMS analysis showed that the root and leaf of $A$. excelsa and $M$. azedarach contained 5 types of allelochemicals compounds grouped to phenols, fatty acids and terpenoids. The twig of $A$. excelsa and $M$. azedarach contained 6 types of allelochemical compounds grouped to phenols, fatty acids and alcohols. According to Harbone (1999), phenolic acids and fatty acids were the compounds which were capable of inhibiting the growth and development of other plants.

Chemical compound under phenol group are eugenol, 4-allyl-2,6-dimethoxyphenol, 2.6-dimethoxyphenol, 3,5xylenol, p-cresol and syringaldehide. Fatty acids groups consisted of nonoic acid, stearic acid, oleic acid, lauric acid, palmitic acid and myristic acid. Alcohol groups consisted of coniferyl alcohol and 2,5-dimethoxybenzyl alcohol, whereas the phytol compound is grouped to terpenoids.

Several studies suggested that the compounds found in A. excelsa and $M$. azedarach could provide inhibitory effects on the growth of other plants. The study results of Ahuja et al. (2014) showed that eugenol could inhibit the germination and early growth of Avena fatua. In addition, eugenol is also toxic to some species of weeds such as Taraxacum officinale, Amaranthus retroflexus, Ageratum conyzoides, so the eugenol has the potential to be used as bioherbicide.

Nonanoic acid or pelargonic acid is a potential bioherbicide that can control duckweed growth in aquatic environments. According to Webber (2009), pelargonic acid was able to control the growth of duckweed up to $99 \%$ or more at a concentration of $0.00975 \%(\mathrm{v} / \mathrm{v})$ after three days of application. Arachidic acid, behenic acid, palmitic acid and stearic acid were allelopathic to the rice plant. At a concentration of $250 \mathrm{ppm}$, the chemical compounds can inhibit the germination of rice (Xuan \& Tsuzuki 2004). In addition to the rice plants, palmitic acid with oleic acid can also inhibit the germination and root growth of Arabidopsis thaliana (Angelini et al. 2014). 
Table 1. The result of allelochemical analysis of Azadirachta excelsa and Melia azedarach

\begin{tabular}{|c|c|c|c|c|c|c|}
\hline \multirow{3}{*}{ Chemical compound } & \multicolumn{2}{|c|}{ Root } & \multicolumn{2}{|c|}{ Leaf } & \multicolumn{2}{|c|}{ Twig } \\
\hline & A. excelsa & M. azedarach & A. excelsa & M. azedarach & A. excelsa & M. azedarach \\
\hline & \multicolumn{6}{|c|}{$\%$} \\
\hline Eugenol & 2.69 & 5.59 & - & - & 0.84 & - \\
\hline Nonoic acid & 8.15 & 5.56 & - & - & - & - \\
\hline 4-Allyl-2,6-dimethoxyphenol & 4.17 & 4.60 & - & - & 7.82 & 8.22 \\
\hline 2.6-Dimethoxyphenol & 3.00 & 3.58 & - & - & 3.60 & 2.77 \\
\hline Stearic acid & - & 2.91 & 6.17 & - & - & - \\
\hline Oleic acid & 1.26 & - & 4.71 & 4.07 & - & 0.83 \\
\hline Palmitic acid & - & - & - & - & 0.48 & - \\
\hline Lauric acid & - & - & 3.90 & 3.20 & - & - \\
\hline p-cresol & - & - & - & 1.22 & - & - \\
\hline Phytol & - & - & 6.01 & 4.82 & - & - \\
\hline 3,5-xylenol & - & - & - & 1.18 & - & - \\
\hline Coniferyl alcohol & - & - & - & - & 4.92 & 4.42 \\
\hline 2,5-Dimethoxybenzyl alcohol & - & - & - & - & 5.28 & 4.31 \\
\hline Syringaldehide & - & - & - & - & - & 1.48 \\
\hline Myristic acid & - & - & 4.68 & - & - & - \\
\hline
\end{tabular}

Table 2. The effect of root, leaf and twig extracts of Azadirachta excelsa and Melia azedarach on germination rate and percentage of abnormal sprouts of soybean

\begin{tabular}{|c|c|c|c|c|c|}
\hline \multirow{2}{*}{ Part of plant } & \multirow{2}{*}{$\begin{array}{l}\text { Concentration } \\
(\%)\end{array}$} & \multicolumn{2}{|c|}{ Germination rate $(\%)$} & \multicolumn{2}{|c|}{ Abnormal sprouts (\%) } \\
\hline & & A. excelsa & M. azedarach & A. excelsa & M. azedarach \\
\hline \multirow[t]{4}{*}{ Root } & 0.00 & $84.00^{\mathrm{ab}}$ & $72.00^{\mathrm{abcd}}$ & $16.00^{\mathrm{fg}}$ & $28.00^{\text {defg }}$ \\
\hline & 1.25 & $84.00^{\mathrm{ab}}$ & $68.00^{\text {bcde }}$ & $16.00^{\mathrm{fg}}$ & $32.00^{\text {cdef }}$ \\
\hline & 2.50 & $78.67^{\mathrm{abc}}$ & $65.33^{\text {cde }}$ & $21.33^{\mathrm{efg}}$ & $34.67^{\text {cde }}$ \\
\hline & 5.00 & $13.33^{\mathrm{g}}$ & $38.67^{\mathrm{f}}$ & $86.67^{\mathrm{a}}$ & $61.33^{\mathrm{b}}$ \\
\hline \multirow[t]{4}{*}{ Leaf } & 0.00 & $74.67^{\mathrm{abcd}}$ & $72.00^{\mathrm{abcd}}$ & $25.33^{\text {defg }}$ & $28.00^{\text {defg }}$ \\
\hline & 1.25 & $77.33^{\mathrm{abcd}}$ & $52.00^{\text {ef }}$ & $22.67^{\text {defg }}$ & $48.00^{\mathrm{bc}}$ \\
\hline & 2.50 & $77.33^{\mathrm{abcd}}$ & $69.33^{\text {bcd }}$ & $22.67^{\text {defg }}$ & $30.67^{\text {def }}$ \\
\hline & 5.00 & $38.67^{\mathrm{f}}$ & $21.33^{\mathrm{g}}$ & $61.33^{\mathrm{b}}$ & $78.67^{\mathrm{a}}$ \\
\hline \multirow[t]{4}{*}{ Twig } & 0.00 & $72.00^{\mathrm{abcd}}$ & $86.67^{\mathrm{a}}$ & $28.00^{\mathrm{defg}}$ & $13.33^{\mathrm{g}}$ \\
\hline & 1.25 & $74.67^{\mathrm{abcd}}$ & $80.00^{\mathrm{abc}}$ & $25.33^{\mathrm{defg}}$ & $20.00^{\text {efg }}$ \\
\hline & 2.50 & $65.33^{\text {cde }}$ & $61.33^{\mathrm{de}}$ & $34.67^{\text {cde }}$ & $338.67^{\mathrm{cd}}$ \\
\hline & 5.00 & $66.67^{\text {cde }}$ & $6.67^{\mathrm{g}}$ & $33.33^{\text {cde }}$ & $93.33^{\mathrm{a}}$ \\
\hline
\end{tabular}

Note: The numbers followed by the same letter in the same column are not significantly different at 5\% level test (Duncan multiple range test)

Coniferyl alcohol is the defense compound of a phytoalexin type included in propanoid phenyl group. It has the allelopathic potential with a weak inhibitory effect. According to Kalinova et al. (2011), coniferyl alcohol showed a weak inhibitory effect on the germination of Plantago lanceolata L. compared with eugenol. Lauric acid identified from the plant Rehmannia glutinosa was proven to provide inhibitory effect on germination, root length and fresh weight of sesame plants. Phenols such as $p$-cresol and syringaldehide are able to inhibit the growth of other plants. P-cresol can disrupt the photosynthesis process and respiration of water plants and can also inhibit the pollen germination of Impatiens sultanii at concentration of 100-125 ppm (Bilderback 1981). Syringaldehide can provide inhibitory effect on germination of Echinochola cruss-galli.

Apart from providing the inhibitory effect, the chemical compounds contained in $A$. excelsa could also provide stimulant effect on the germination of soybean at a very low level. The root, leaf, and twig of A. excelsa contained ammonium carbamate compound. This compound is generally used as a raw material for urea fertilizer. Therefore, the stimulant effects of plant extracts of $A$. excelsa might arise because of the presence of ammonium carbamate compound.

\section{Normality of Soybean Sprouts}

The application of $A$. excelsa and $M$. azedarach extracts significantly affected the germination rate and the percentage of abnormal soybean sprouts. The percentage of germination of soybean control ranged from $72-86.67 \%$ and decreased along with the increasing of the extract concentration. The germination percentages of soybean sprouts with the extract (1.25\% of $A$. excelsa twig, $1.25 \%$ and $2.5 \%$ of $A$. excelsa leaf) were greater than the control. The greatest inhibitory effect on the germination of soybean occurred in the soybean treated with $5 \%$ root extract of A. excelsa, 5\% leaf extract of M. azedarach, and 
$5 \%$ twig extracts of $M$. azedarach (Table 2). Abnormal germination percentage was negatively related to soybean germination. The higher the concentration applied, the lower the rate of soybean germination and the higher percentage of abnormal germination.

The decrease of germination rate of soybean as a result of the extract of $A$. excelsa and $M$. azedarach at various concentrations indicated the presence of allelopathic effect. The effect of allelopathic arose because of the interaction of several allelochemical compounds such as phenols, fatty acids, and alcohols. According to Aisah (2016), the interactions between the allelochemical compounds would produce optimal inhibition compared with inhibition by a single allelochemical.

The previous study has proven that allelochemical compounds released into the environment might affect the germination of surrounding plants. According to Hong et al. (2003), extracts of $M$. azedarach could provide a significant inhibition of Raphanus sativus $L$. germination with a percentage of $58.1 \%$.

The analysis results of the chemical compound showed that the part of $A$. excelsa and $M$. azedarach contained allelochemical compounds of phenols, fatty acids, and alcohols which were capable of inhibiting the germination of plants. According to Einhellig (1996), the inhibitory mechanism of phenolics has begun with the structure degradation of the plasma membrane, membrane channel modification, or the loss function of the ATPase. Phenolic allelochemical can also lead to increased cell membrane permeability. Consequently, cell content spill and there is increased lipid peroxidation. Finaly, there is slow growth leading to death of plant tissue ( $\mathrm{Li}$ et al. 2010). According to Aisah (2016), phenol might cause the biosynthesis disruption of nucleotides and prevent gibberellin biosynthesis, thereby inhibiting the germination of soybean.

Supriatno (1995) stated that the inhibition during early germination phase was generally followed by the failure of the mobilization of food reserves to the growing point of sprouts. Inhibition of soybean germination by $M$. azedarach and root extract of $A$. excelsa produced abnormal sprouts with low quality. The results showed the abnormal germination conditions such as the imperfect appearance of the radicle, twisted root, and nonsimultaneous germination. The abnormal germination of soybean would result in lower soybean germination rate.

The effect of phenol on the seed germination process depended on its concentration. The higher concentration of phenol in the water, the greater allelopathic effect. This research showed that the application of the root, leaf, and twig extracts of $A$. excelsa and $M$. azedarach at concentrations of $5 \%$ showed the greater inhibition of soybean germination rate than that concentration of $1.25 \%$ and $2.5 \%$.

Table 2 show that the germination percentages of soybean sprouts with the extract $(1.25 \%$ of $A$. excelsa twig, $1.25 \%$ and $2.5 \%$ of $A$. excelsa leaf) were greater than the control and provide stimulant effect on the germination of soybean. When a number of allelopathic compound are released into the environment, the addition of a number of nutrients has occured and had a stimulant effect on the germination of other plants (Hong et al. 2003). This is thought to be caused by the ammonium carbamate compound contained in the extract of $A$. excelsa. This compound is commonly used as a raw material for urea fertilizers which are able to provide the needs of nitrogen for plants. It is possible that the other compounds can also provide stimulant effect on the soybean germination. According to Rice (1984), inhibiting organic compounds at a concentration level can provide stimulation effects at other concentrations.

Allelopathic activity of the extract solution was measured using the response index value (RI) of soybean germination (Hu et al. 2013). RI value $<0$ indicated that the extract solution provided inhibitory effect, while the value of $\mathrm{RI}>0$ indicated that the extract solution provided stimulant effect on soybean plants. 2.5\% root extract of $A$. excelsa, $1.25 \%$ and $2.5 \%$ root extract of $M$. azedarach, $2.5 \%$ leaf extract of $M$. azedarach and $1.25 \%$ twig extract of $M$. azedarach provided a lower inhibitory effect on the soybean germination (Figure 1). This might be caused by the low concentration of allelochemical substances contained in the extract solution. The lowest response index was found in $A$. excelsa root extract and $M$. azedarach twig extract at a concentration of $5 \%$. At this concentration, the root extract of $A$. excelsa provided the greatest inhibitory effect on soybean germination.

\section{Sprouts growth}

The extracts of $A$. excelsa and $M$. azedarach significantly affected the soybean radicle length but did not significantly affect the length of soybeans plumule. Soybean treated with extracts of $A$. excelsa and $M$. azedarach showed a lower radicle length than the control. The greatest inhibition of radicle growth was found in soybeans treated with extracts of $A$. excelsa and $M$. azedarach at concentration of 5\% (Table 3). Extracts of $A$. excelsa and $M$. azedarach did not significantly affect the plumule length of soybean sprouts, the plumule length tended to decrease along with the increasing of extract concentration provided.

Extracts of $A$. excelsa and $M$. azedarach at each concentration showed different inhibitory effects on the radicle growth of soybean sprouts. The greater the concentration applied, the higher the inhibitory effect and the shorter radicle length of soybean. The greatest inhibition percentage was found in root extract of $A$. excelsa at concentration of 5\% (Figure 2). Leaf extract of $M$. azedarach at a concentration of $5 \%$ also provided large percentage of radicle growth inhibition, by $77.75 \%$. The smallest inhibition percentage was found in root and twig extracts of $A$. excelsa at concentration of $1.25 \%$. 
Table 3. The effect of root, leaf, and twig extracts of Azadirachta excelsa and Melia azedarach on soybean sprouts radicle length

\begin{tabular}{|c|c|c|c|c|c|}
\hline \multirow{2}{*}{ Part of Plant } & \multirow{2}{*}{$\begin{array}{l}\text { Concentration } \\
(\%)\end{array}$} & \multicolumn{2}{|c|}{ Radicle lenght (cm) } & \multicolumn{2}{|c|}{ Plumule lenght $(\mathrm{cm})$} \\
\hline & & A. excelsa & M. azedarach & A. excelsa & M. azedarach \\
\hline \multirow[t]{4}{*}{ Root } & 0.00 & $14.02^{\mathrm{a}}$ & $12.88^{\mathrm{ab}}$ & $3.28^{\mathrm{a}}$ & $3.23^{\mathrm{a}}$ \\
\hline & 1.25 & $13.52^{\mathrm{ab}}$ & $11.12^{\text {bcde }}$ & $1.99^{\mathrm{a}}$ & $2.44^{\mathrm{a}}$ \\
\hline & 2.50 & $8.38^{\text {fghi }}$ & $7.46^{\mathrm{ghi}}$ & $1.25^{\mathrm{a}}$ & $1.55^{\mathrm{a}}$ \\
\hline & 5.00 & $2.54^{\mathrm{mn}}$ & $5.01^{\mathrm{jkl}}$ & $0.57^{\mathrm{a}}$ & $0.93^{\mathrm{a}}$ \\
\hline \multirow[t]{4}{*}{ Leaf } & 0.00 & $12.81^{\mathrm{ab}}$ & $12.38^{\mathrm{abc}}$ & $3.54^{\mathrm{a}}$ & $3.03^{\mathrm{a}}$ \\
\hline & 1.25 & $11.43^{\text {bcde }}$ & $9.49^{\text {efgh }}$ & $2.81^{\mathrm{a}}$ & $2.99^{\mathrm{a}}$ \\
\hline & 2.50 & $10.36^{\text {cdef }}$ & $7.18^{\text {hij }}$ & $2.31^{\mathrm{a}}$ & $1.99^{\mathrm{a}}$ \\
\hline & 5.00 & $3.87^{\operatorname{lmn}}$ & $4.66^{\mathrm{klm}}$ & $0.98^{\mathrm{a}}$ & $1.22^{\mathrm{a}}$ \\
\hline \multirow{4}{*}{ Twig } & 0.00 & $12.28^{\mathrm{abc}}$ & $11.65^{\text {abcde }}$ & $4.15^{\mathrm{a}}$ & $1.83^{\mathrm{a}}$ \\
\hline & 1.25 & $12.08^{\mathrm{abcd}}$ & $9.72^{\operatorname{defg}}$ & $3.61^{\mathrm{a}}$ & $1.61^{\mathrm{a}}$ \\
\hline & 2.50 & $8.62^{\text {fghi }}$ & $6.37^{\mathrm{ijk}}$ & $1.97^{\mathrm{a}}$ & $1.18^{\mathrm{a}}$ \\
\hline & 5.00 & $6.42^{\mathrm{ijk}}$ & $2.35^{\mathrm{n}}$ & $1.70^{\mathrm{a}}$ & $0.70^{\mathrm{a}}$ \\
\hline
\end{tabular}

Note: The numbers followed by the same letter in the same column are not significantly different at $5 \%$ level test (Duncan multiple range test)

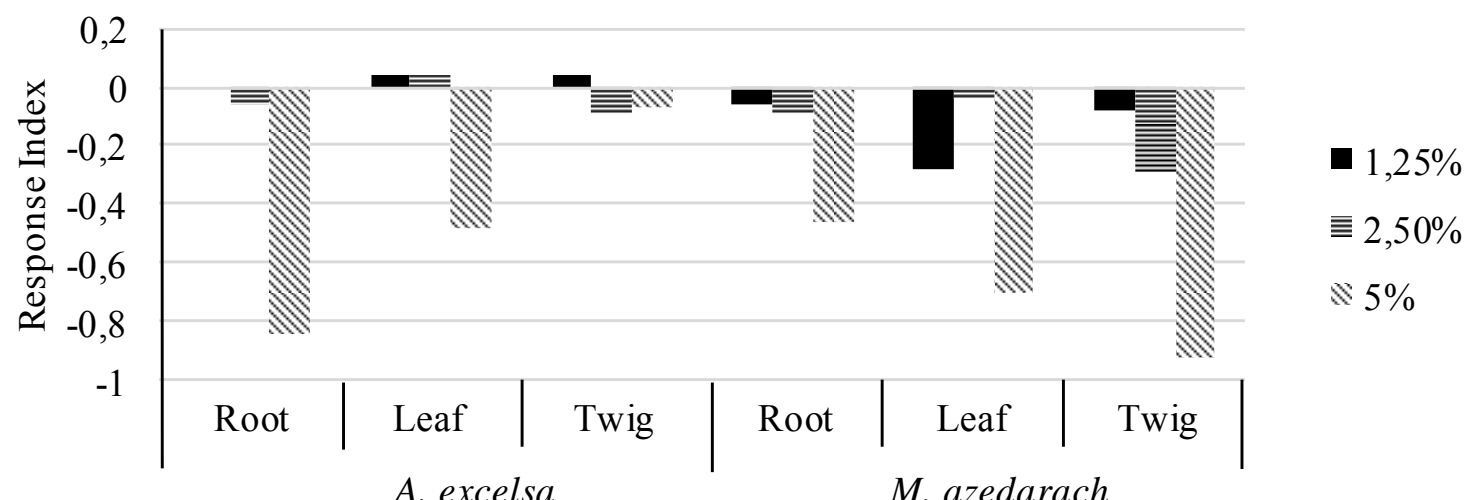

Figure 1. Response index of soybean germination to the extract of Azadirachta excelsa and Melia azedarach

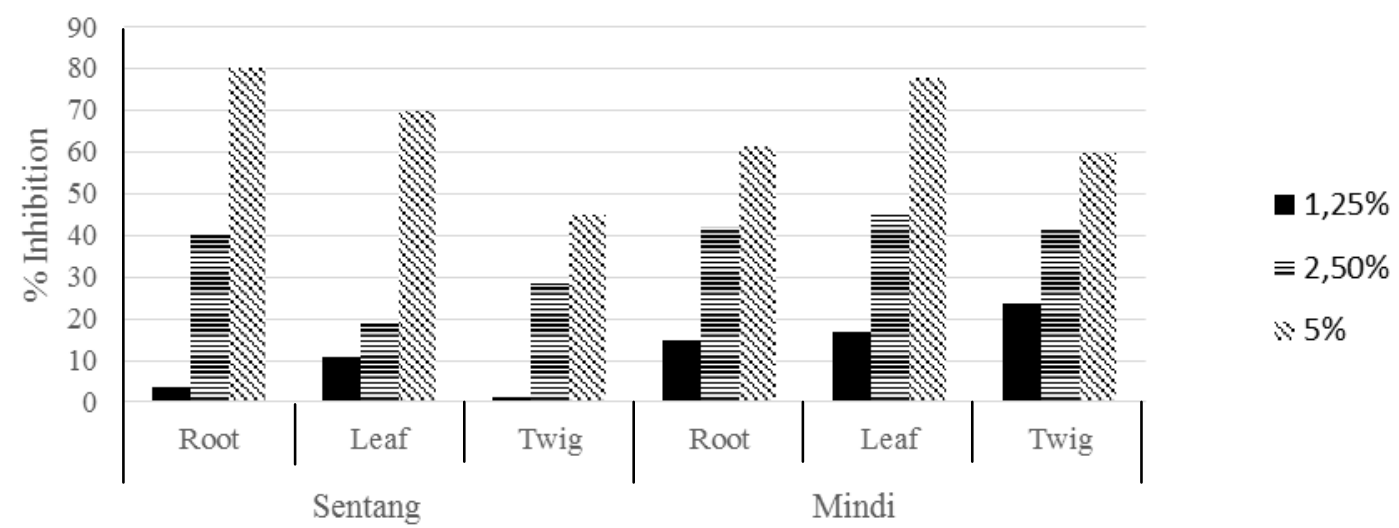

Figure 2. Inhibition percentage of Azadirachta excelsa and Melia azedarach extract solution 
The lower radicle length of soybean sprouts treated with $A$. excelsa and $M$. azedarach extracts than the control indicated the presence of the allelopathic effect. Allelochemical compounds can interfere phytohormones system, whereas growth hormones such as auxin, cytokinin, and gibberellin are very important during the cell division and cell elongation (Aisah 2016). According to Pebriani et al. (2013), phenolic compounds can inhibit the cytokines activity which play significant role in the mitosis process. Growth Inhibition of soybean sprouts caused by the failure of the food reserves mobilization to growing point on plumule and radicle.

In conclusion, root, leaf and twig of $A$. excelsa and $M$. azedarach contained allelochemicals compounds grouped to phenols, fatty acids, alcohol and terpenoids which might provide an allelopathic effect and inhibit the germination of soybean. A. excelsa and $M$. azedarach extract at 5\% concentration provide inhibitory effect on soybean germination, but also could provide stimulant effect at lower concentration. It is necessary to screen for allelopathic compound contained in Root, leaf and twig of A. excelsa and $M$. azedarach and to be tested separately so that it can be known which chemical compounds will have a significant inhibitory effect.

\section{REFERENCES}

Ahuja N, Singh HP, Batish DR, Kohli RK. 2015. Eugenol-inhibited root growth in Avena fatua involves ROS-mediated oxidative damage. Pesticides Biochem Physiol 118: 64-70.

Aisah S. 2016. Allelopathy Potential of Alpinia malaccensis (Burm. F.) Roxb. to Invasive Species Merremia peltata (L.) Merrill. [Thesis]. Bogor Agricultural University, Bogor. [Indonesian]

Angelini P, Tirillini B, Properzi A, Rol C, Venanzoni R. 2014 Identification and bioactivity of the growth inhibitors in Tuber spp. methanolic extracts. Plant Biosyst 149: 1000-1009.

Bhowmik PC, Inderjit. 2003. Challenges and opportunities in implementing allelopathy for natural weed management. Crop Prot. 22: 661-671.
Bilderback DE. 1981. Impatiens pollen germination and tube growth as a bioassay for toxic substances. Environ Health Perspect 37: 95-103.

Einhellig FA. 1996. Interactions involving allelopathy in cropping systems. Agron J 88:886-893.

Hong HN, Xuan DT, Eiji T, Hiroyuki T, Mitsuhiro M, Khanh TD. 2003. Screening for allelopathic potential of higher plants from Southeast Asia. Crop Protection 22: 829-836.

$\mathrm{Hu}$ B, Hu G, Zhang Z. 2013.Allelopathic potential of leaf litter extracts of the invasive Chromolaena odorata on itsneighboring plants. J Food Agric Environ 11 (3-4): 2561-2566.

Kalinova J, Triska J, Vrchotova N. 2011. Occurence of eugenol, coniferyl alcohol and 3,4,5-trimethoxyphenol in common buckwheat (Fagopyrum esculentum Moench) and their biological activity. Acta Physiol Plant 33: 1679-1685.

Li ZH, Wang, Q, Ruan X, Pan CD, Jiang DA. 2010.Phenolics and plant allelopathy. Molecules 15: 8933-8952.

Lungu L, Popa CV, Morris J, Savoiu M. 2011. Evaluation of phytotoxic activity of Melia azedarach L. extracts on Lactuca sativa L. Romanian Biotechnol Lett 16 (2): 6089-6095.

Pebriani, Linda R, Mukarlina. 2013. Extract potential of Mikania micrantha H.B.K as bioherbicide to Cleome rutidosperma D.C and Paspalum notatum Flugge. Protobiont 2 (2): 32-38.

Sangheeta C, Baskar P. 2015. Allelopathy in weed anagement: a critical review. African J Agric Res 10 (9): 1004-1015.

Sen A, Batra A. 2012. Chemical composition of methanol extract of the leaf of Melia azedarach L. Asian J Pharm Clin Res 5 (3): 42-545.

Shapla TL, Parvin R, Amin MHA, Rayhan SM. 2011. Allelopathic effects od multipurpose tree species Melia azedarach with emphasis on agricultural crops. J Innov Dev Strat 5:70-77.

Supriatno. 1995. Seed Germination of Several Legumes Due to Herbicide Alachlor Treatment in Different Concentration and Time of Application. [Thesis]. Gajah Mada University, Yogyakarta. [Indonesian]

Tsao R, Romanchuk FE, Peterson CJ, Coats JR. 2002. Plant growth regulatory effect and insecticidal activity of th extracts of the Tree of Heaven (Ailanthus altissima L.). BMC Ecol 2 (1): 1-6.

Webber CL, Shrefler JW, Taylor MJ. 2014. Adjuvants affect duckweed (Lemma minor) control with pelargonic acid. J Agric Sci 6 (12): 1-8.

Wibowo ARP. 2012. Agroforestry Between Sentang (Azadirachta excelsa Jack) and Sorgum (Sorghum bicolor L. Moench). [Thesis]. Bogor Agricultural University, Bogor. [Indonesian]

Widajati E, Murniati E, Palupi ER, Kartika T, Suhartanto MR, Qadir A. 2012. Seed Science and Technology. BAU Pr, Bogor. [Indonesian]

Xuan TD, Tsuzuki E. 2004. Allelopathic plants: buckwheat. Allelopathy J 13: 137-148. 